\title{
FAKTOR-FAKTOR YANG BERHUBUNGAN DENGAN KETIDAKPATUHAN MASYARAKAT TERHADAP PROTOKOL KESEHATAN PADA MASA PANDEMI COVID-19
}

\author{
Factors Related To Community Non-Compliance With Health Protocols During The \\ Covid-19 Pandemic \\ Zahroh $^{1}$, Ervi Suminar ${ }^{2}$ \\ ${ }^{1.2 .}$ Prodi Keperawatan Universitas Muhammadiyah Gresik \\ Alamat Korespondensi : Prodi Keperawatan UMG \\ Jl. Proklamasi No. 54 Gresik -Jawa Timur- Indonesia \\ Email : ervi.suminar@umg.ac.id
}

\begin{abstract}
ABSTRAK
Covid-19 menjadi sebuah wabah penyakit sejak tahun 2019, dimana penanganan dan pencegahannya dapat dilakukan dengan menerapkan protokol kesehatan $5 \mathrm{M}$ dengan benar yaitu Memakai masker, Mencuci tangan pakaisabun dan air mengalir, Menjaga jarak, Menjauhi kerumunan serta Membatasi mobilitas dan interaksi. Implementasi protokol kesehatan tersebut tidak akan maksimal apabila tidak didukung oleh masyarakat. Tujuan dari penelitian ini adalah untuk mengetahui faktor-faktor yang berhubungan dengan ketidakpatuhan masyarakat terhadap protokol kesehatan pada masa pandemi covid-19. Metode yang digunakan dalam penelitian ini adalah penelitian analitik dengan pendekatan cross sectional. populasi dalam penelitian ini adalah seluruh masyarakat Dusun Toba Laok Bulukagung dengan jumlah sampel 123 responden, teknik sampling yang digunakan adalah random sampling. Pengumpulan data dilakukan menggunakan kuesioner secara online. Analisa data yang digunakan dalam penelitian ini berupa analisis bivariat Rank Spearman. Berdasarkan hasil analisis menggunakan Rank Spearman didapatkan bahwa terdapat lima faktor yang memiliki hubungan yang signifikan dengan ketidakpatuhan masyarakat terhadap protokol kesehatan yaitu aspek psikologis (p 0,000), aspek sosial (p 0,000), dan persepsi terhadap pemerintah ( $\mathrm{p} 0,000)$.
\end{abstract}

Kata kunci : covid-19; ketidakpatuhan masyarakat; protokol kesehatan

\begin{abstract}
Covid-19 has become a disease since 2019, where handling and prevention can be done by applying the 5M health protocol correctly, namely using health protocols, washing hands using soap and running water, maintaining distance, long distance, and limiting interactions and interactions. The implementation of the health protocol will not be optimal if it is not supported by the community. The purpose of this study was to determine the factors associated with public noncompliance with health protocols during the COVID-19 pandemic.The method used in this study is an analytical study with a cross sectional approach. The population in this study was the entire community of Dusun Toba Laok Bulukagung with a sample of 123 respondents, the sampling technique used was random sampling. Data collection was carried out using an online questionnaire. Analysis of the data used in this study in the form of bivariate analysis of Rank Spearman. Based on the results of the analysis using Rank Spearman, it was found that there are three factors that have a significant relationship with community non-compliance with health protocols, namely psychological aspects ( $p$ 0.000), social ( $p$ 0.000), and perceptions of the government ( $p$ 0.000).
\end{abstract}

Keywords : covid-19; community disobedience; health protocol 


\section{PENDAHULUAN}

Severe acute respiratory syndrome coronavirus 2 (SARS-CoV-2) atau yang sering disebut Covid-19 disebabkan oleh jenis virus yang bernama coronavirus dan dapat menular. Ditemukan pada tahun 2019 dan menjadi sebuah pandemi di seluruh negara dunia termasuk Indonesia. Covid-19 dapat mengakibatkan gangguan pada sistem pernapasan seperti batuk, pilek, berkurang atau hilangnya indra penciuman, infeksi paru-paru berat, hingga kematian. Virus ini dapat menyerang siapa saja yang memiliki imunitas rendah, seperti bayi, ana-anak, lansia, orang dewasa, ibu hamil dan menyusui (WHO, 2020).

Berdasarkan data statistik Covid-19 dunia pada 2 November 2020 secara global terdapat 46.426.677 kasus pasien positif, 1.199.684 kasus diantaranya dinyatakan meninggal dan 31.017.303 kasus dinyatakan sembuh dari Covid-19 (Natasha Khairunisa 2020). Indonesia tercatat 415.402 kasus pasien positif Covid-19, 345.566 kasus pasien sembuh dengan jumlah 14.044 orang meninggal (Dhimas 2020). Pasien positif Covid-19 di Jawa Timur sebanyak 55.137 kasus. Selain kasus positif, angka kematian di Jawa Timur juga tercatat sebanyak 3.933 kasus. Jawa Timur juga tercatat jumlah pasien sembuh sebanyak 49.113 kasus pasien sembuh dari Covid-19 (Melani 2020).

Tingkat kesadaran dan pengetahuan warga Kecamatan Klampis, kabupaten Bangkalan terhadap Covid-19 dan pencegahan penyebaran Virus Corona (Covid-19) masih sangat rendah. Banyak warga yang mengabaikan protokol kesehatan seperti tidak memakai masker, tidak mencuci tangan, dan tetap mengadakan acara yang dapat menimbulkan kerumunann seperti acara pernikahan, pengajian dan lain-lain. Sehingga menempatkan Kecamatan Klampis dalam status sebagai wilayah yang berisiko sedang dengan jumlah orang yang terkonfirmasi positif Covid-19 sebanyak 32 orang (DinKes Bangkalan 2021).

\section{METODE}

Metode yang digunakan dalam penelitian ini adalah penelitian analitik dengan pendekatan cross sectional. populasi dalam penelitian ini adalah seluruh masyarakat Dusun Toba Laok Bulukagung Klampis dengan jumlah sampel sebanyak 123 responden, teknik sampling yang digunakan adalah random sampling. Pengumpulan data dilakukan pada bulan Maret-April 2021, menggunakan kuesioner yang disebarkan melalui WhatsApp secara online. Analisa data yang digunakan dalam penelitian ini berupa analisis bivariat Rank Spearman.

\section{HASIL DAN PEMBAHASAN}

\section{Data Umum}

Tabel 1. Distribusi Frekuensi Berdasarkan Karakteristik Responden Dsn. Toba Laok Bulukagung Tahun 2021

\begin{tabular}{llll}
\hline No & $\begin{array}{c}\text { Karakteristik } \\
\text { Responden }\end{array}$ & n & (\%) \\
\hline $\mathbf{1}$ & Jenis Kelamin & & \\
& Laki-laki & 70 & 56,9 \\
& Perempuan & 53 & 43.1
\end{tabular}




\begin{tabular}{llll}
$\mathbf{2}$ & Usia & & \\
& $16-20$ & 36 & 29,3 \\
& $21-30$ & 46 & 37,4 \\
& $31-40$ & 41 & 33,3 \\
$\mathbf{3}$ & Agama & & \\
& Islam & 123 & 100 \\
\hline & Total & $\mathbf{1 2 3}$ & $\mathbf{1 0 0}$ \\
\hline
\end{tabular}

Sumber : Data Primer 2021

Tabel 1 menunjukkan bahwa sebagian besar $(56,9 \%)$ responden berjenis kelamin laki-laki, berusia 21-30 tahun (37,4\%), dan seluruh responden $(100 \%)$ menganut agama Islam.

\section{Data Khusus}

Tabel 2. Distribusi Frekuensi Responden Berdasarkan Aspek Psikologis di Dsn. Toba Laok Tahun 2021

\begin{tabular}{llcc}
\hline No & $\begin{array}{c}\text { Aspek } \\
\text { Psikologis }\end{array}$ & n & (\%) \\
\hline 1 & Rendah & 24 & 19,5 \\
2 & Sedang & 84 & 68,3 \\
3 & Tinggi & 15 & 12,2 \\
\hline & Total & $\mathbf{1 2 3}$ & $\mathbf{1 0 0}$ \\
\hline
\end{tabular}

Sumber : Data Primer 2021

Berdasarkan hasil penelitian didapatkan responden dengan aspek psikologis rendah sebanyak 24 orang (19,5\%), aspek psikologis sedang 84 orang $(68,3 \%)$ dan responden dengan aspek psikologis tinggi sebanyak 15 orang $(12,2 \%)$.

Tabel 3. Distribusi frekuensi Responden Berdasarkan Aspek Sosial di Dsn. Toba Laok Tahun 2021

\begin{tabular}{cccc}
\hline No & $\begin{array}{c}\text { Aspek } \\
\text { Sosial }\end{array}$ & $\mathbf{n}$ & $\mathbf{( \% )}$ \\
\hline 1 & Rendah & 28 & 22,8 \\
2 & Sedang & 76 & 61,8 \\
3 & Tinggi & 19 & 15,4 \\
\hline & Total & $\mathbf{1 2 3}$ & $\mathbf{1 0 0}$ \\
\hline
\end{tabular}

Sumber : Data Primer 2021

Berdasarkan hasil penelitian didapatkan sebagian responden dengan aspek sosial rendah sebanyak 28 orang $(22,8 \%)$, sedang 76 orang $(61,8 \%)$ dan responden dengan aspek sosial tinggi sebanyak 19 orang $(15,4 \%)$.

Tabel 4. Distribusi frekuensi Responden Berdasarkan Persepsi Terhadap Pemerintah di Dsn. Toba Laok Tahun 2021

\begin{tabular}{llll}
\hline No & $\begin{array}{c}\text { Persepsi } \\
\text { Terhadap } \\
\text { Pemerintah }\end{array}$ & n & $\mathbf{( \% )}$ \\
\hline 1 & Rendah & 25 & 20,3 \\
2 & Sedang & 81 & 65,9 \\
3 & Tinggi & 17 & 13,8 \\
\hline & Total & $\mathbf{1 2 3}$ & $\mathbf{1 0 0}$ \\
\hline
\end{tabular}

Sumber : Data Primer 2021

Berdasarkan hasil penelitian didapatkan responden dengan persepsi terhadap pemerintah rendah sebanyak 25 orang $(20,3 \%)$, sedang sebanyak 81 orang $(65,9 \%)$ dan responden dengan persepsi terhadap pemerintah tinggi sebanyak 17 orang $(13,8 \%)$.

Tabel 5. Distribusi frekuensi Responden Berdasarkan Ketidakpatuhan Protokol Kesehatan di Dsn. Toba Laok Tahun 2021

\begin{tabular}{llcc}
\hline No & $\begin{array}{c}\text { Ketidakpatuhan } \\
\text { ProKes }\end{array}$ & n & $(\boldsymbol{\% )})$ \\
\hline 1 & Rendah & 11 & 8,9 \\
2 & Sedang & 92 & 74,8 \\
3 & Tinggi & 20 & 16,3 \\
\hline & Total & $\mathbf{1 2 3}$ & $\mathbf{1 0 0}$ \\
\hline
\end{tabular}

Sumber : Data Primer 2021

Berdasarkan hasil penelitian didapatkan responden dengan ketidakpatuhan terhadap protokol kesehatan rendah sebanyak 11 orang $(8,9 \%)$ sedang sebanyak 92 orang $(74,8 \%)$ dan responden dengan ketidakpatuhan terhadap protokol kesehatan tinggi sebanyak 20 orang $(16,3 \%)$. 


\section{Analisis Bivariat}

Analisis bivariat dilakukan untuk mengetahui hubungan antara variabel independen dan variabel dependen. Berdasarkan hasil penelitian yang dilakukan, maka tabulasi silang antara variabel independen dan variabel dependent dapat dilihat pada tabel di bawah ini:

Tabel 6. Hasil Tabulasi Silang Aspek Psikologis Dengan Ketidakpatuhan Protokol Kesehatan di Dusun Toba Laok Tahun 2021

\begin{tabular}{lcccc}
\hline \multicolumn{5}{c}{ Ketidakpatuhan Protokol Kesehatan } \\
\hline \multicolumn{1}{c}{$\begin{array}{c}\text { Aspek } \\
\text { psikologis }\end{array}$} & Rendah & Sedang & Tinggi & Total \\
\cline { 2 - 5 } Rendah & & & & \\
Sedang & 0 & 5 & 19 & 24 \\
Tinggi & 11 & 4 & 1 & 84 \\
\hline Total & 11 & 92 & 20 & 123 \\
\hline Uji Rank & Sig & & 0,000 & \\
\cline { 2 - 5 } Spearman & Crl & & $-0,860$ & \\
\hline
\end{tabular}

Berdasarkan hasil uji tabulasi silang antara aspek psikologis dengan ketidakpatuhan protokol kesehatan didapatkan aspek psikologis kategori sedang sebagian besar warga Dusun Toba Laok melakukan ketidakpatuhan protokol kesehatan sedang sebanyak $83 \quad(98,8 \%)$, dibandingkan aspek psikologis kategori rendah sebanyak 5 (20,8\%) dan aspek psikologis kategori tinggi sebanyak 4 $(26,7 \%)$. Aspek psikologis kategori rendah sebagian besar warga Dusun Toba Laok melakukan ketidakpatuhan protokol kesehatan tinggi yaitu sebanyak 19 (79,2\%), dibandingkan aspek psikologis kategori sedang sebanyak 1 (1,2\%) dan aspek psikologis kategori tinggi sebanyak $0(0,0 \%)$. Aspek psikologis kategori tinggi sebagian besar warga Dusun Toba Laok melakukan ketidakpatuhan protokol kesehatan tinggi yaitu sebanyak $11(73,3 \%)$, dibandingkan aspek psikologis kategori sedang dan rendah sebanyak $0(0,0 \%)$.

Hasil dari uji Rank Spearman dengan tingkat kesalahan $5 \%(0,05)$ didapatkan nilai Sig $(0,000)<\alpha(0,05)$, maka H1 diterima dan H0 ditolak artinya ada hubungan antara aspek psikologis dengan ketidakpatuhan protokol kesehatan di Dusun Toba Laok Bulukagung Kecamatan Klampis. Nilai Correlation Coefficient sebesar $-0,860$ artinya tingkat hubungan antara variabel aspek psikologis dan ketidakpatuhan protokol kesehatan adalah sangat kuat.

Tabel 7. Hasil Tabulasi Silang Aspek Sosial Dengan Ketidakpatuhan Protokol Kesehatan di Dusun Toba Laok Tahun 2021

\begin{tabular}{lcccc}
\hline \multicolumn{5}{c}{ Ketidakpatuhan Protokol Kesehatan } \\
\hline \multicolumn{1}{c}{ Aspek } & Rendah & Sedang & Tinggi & Total \\
Sosial & & & & \\
\cline { 2 - 5 } Rendah & 0 & 8 & 20 & 28 \\
Sedang & 1 & 75 & 0 & 76 \\
Tinggi & 10 & 9 & 0 & 19 \\
\hline Total & 11 & 92 & 20 & 123 \\
\hline Uji Rank & Sig & & 0,000 & \\
\cline { 2 - 5 } Spearman & Crl & & $-0,787$ & \\
\hline
\end{tabular}

Berdasarkan hasil uji tabulasi silang antara aspek sosial dan ketidakpatuhan protokol kesehatan didapatkan aspek sosial kategori sedang sebagian besar warga Dusun Toba Laok melakukan ketidakpatuhan protokol kesehatan sedang yaitu sebanyak 75 (98,7\%), dibandingkan aspek sosial tinggi sebanyak $9(47,4 \%)$ dan aspek sosial rendah sebanyak $8(28,6 \%)$. Aspek sosial tinggi sebagian besar warga Dusun Toba Laok melakukan ketidakpatuhan protokol 
kesehatan rendah yaitu sebanyak 20 (71,4\%), dibandingkan aspek sosial sedang dan tinggi sebanyak 0 (0,0\%).Aspek sosial rendah sebagian besar warga Dusun Toba Laok melakukan ketidakpatuhan protokol kesehatan tinggi yaitu sebanyak $10(52,6 \%)$, dibandingkan aspek sosial sedang sebanyak 1 $(1,3 \%)$ dan aspek sosial rendah sebanyak 0 $(0,0 \%)$.

Hasil dari uji Rank Spearman dengan tingkat kesalahan 5\% $(0,05)$ didapatkan nilai Sig $(0,000)<\alpha(0,05)$, maka H1 diterima dan H0 ditolak artinya ada hubungan antara aspek sosial dengan ketidakpatuhan protokol kesehatan di Dusun Toba Laok Bulukagung Kecamatan Klampis. Nilai Correlation Coefficient sebesar $-0,787$ artinya tingkat hubungan antara variabel aspek sosial dan ketidakpatuhan protokol kesehatan adalah kuat.

\section{Tabel 8. Hasil Tabulasi Silang Persepsi Terhadap Pemerintah Dengan Ketidakpatuhan Protokol Kesehatan di Dusun Toba Laok Tahun 2021}

\begin{tabular}{lcccc}
\hline \multicolumn{5}{c}{ Ketidakpatuhan Protokol Kesehatan } \\
\hline \multicolumn{1}{c}{ Persepsi } & Rendah & Sedang & Tinggi & Total \\
Terhadap & & & & \\
Pemerintah & & & & \\
\cline { 2 - 5 } Rendah & 0 & 7 & 18 & 25 \\
Sedang & 2 & 77 & 2 & 81 \\
Tinggi & 9 & 8 & 0 & 17 \\
\hline Total & 11 & 92 & 20 & 123 \\
\hline Uji Rank & Sig & & 0,000 & \\
Spearman & Crl & \multicolumn{3}{c}{$-0,749$} \\
\hline
\end{tabular}

Berdasarkan hasil uji tabulasi silang antara persepsi terhadap pemerintah dengan ketidakpatuhan protokol kesehatan didapatkan persepsi terhadap pemerintah kategori sedang sebagian besar warga Dusun Toba Laok melakukan ketidakpatuhan protokol kesehatan sedang yaitu sebanyak 77 $(95,1)$, dibandingkan persepsi terhadap pemerintah tinggi sebanyak $8(47,1 \%)$ dan persepsi terhadap pemerintah rendah 7 $(28,0 \%)$. Persepsi terhadap pemerintah tinggi sebagian besar warga Dusun Toba Laok melakukan ketidakpatuhan protokol kesehatan rendah yaitu sebanyak $18(72,0)$, dibandingkan persepsi terhadap pemerintah sedang sebanyak $2(2,5 \%)$ dan persepsi terhadap pemerintah tinggi sebanyak 0 $(0,0 \%)$. Persepsi terhadap pemerintah rendah sebagian besar warga Dusun Toba Laok melakukan ketidakpatuhan protokol kesehatan tinggi yaitu sebanyak 9 (52,9\%), dibandingkan ketidakpatuhan protokol sedang sebanyak 2 (2,5\%) dan ketidakpatuhan protokol rendah sebanyak 0 $(0,0 \%)$.

Hasil dari uji Rank Spearman dengan tingkat kesalahan $5 \%(0,05)$ didapatkan nilai Sig $(0,000)<\alpha(0,05)$, maka H1 diterima dan H0 ditolak artinya ada hubungan antara persepsi terhadap pemerintah dengan ketidakpatuhan protokol kesehatan di Dusun Toba Laok Bulukagung Kecamatan Klampis. Nilai Correlation Coefficient sebesar $-0,749$ (negatif) artinya tingkat hubungan antara variabel persepsi terhadap pemerintah dan ketidakpatuhan protokol kesehatan adalah kuat.

\section{PENUTUP}

\section{Kesimpulan}

Sebagian besar masyarakat Dusun Toba Laok Bulukagung Kecamatan Klampis memiliki aspek psikologis 
sedang sebanyak $(68,3 \%)$, aspek sosial sedang sebanyak (98,7\%), persepsi terhadap pemerintah sedang sebanyak $(95,1 \%)$, dan melakukan ketidakpatuhan protokol kesehatan sedang sebanyak $(74,8 \%)$.

Ada hubungan yang signifikan antara aspek psikologis, aspek social, dan persepsi terhadap pemerintah dengan ketidakpatuhan masyrakat terhadap protokol kesehatan pada masa pandemi covid-19 di Dusun Toba Laok Bulukagung Klampis.

\section{Saran}

Masyarakat perlu meningkat pengetahuan dan juga kesadaran dalam menerapkan protokol kesehatan guna memutus rantai penularan covid-19.

\section{DAFTAR PUSTAKA}

Dhimas. 2020. "Infografis: Statistik Covid-19 Di Indonesia Senin, 2 November 2020." https://www.google.com/amp/s/fin.co.i d/2020/11/02/infografis-statistik-covid19-di-indonesia-senin-2-november2020/\%3Famp.

DinKes Bangkalan. 2021. "PETA SEBARAN COVID-19 Update Data 2 Januari 2021." http://www.bangkalankab.go.id/v6/read /informasi/345-peta-sebaran-covid-19kabupaten-bangkalan-upadate-data-per2-januari-2021.

Melani, Agustina. 2020. "Update Corona COVID-19 Jawa Timur Pada 10 November 2020." https://m.liputan6.com/surabaya/read/4 405339/update-corona-covid-19-jawatimur-pada-10-november2020?utm_source=Mobile\&utm_mediu $\mathrm{m}=$ copylink\&utm_campaign=copylink.

Natasha Khairunisa. 2020. "Update 2 November: 46,2 Juta Orang Di Dunia Positif COVID-19, Australia Nol Kasus Domistik Sejak Juni." https://m.liputan6.com/global/read/4397 464/update-2-november-464-jutaorang-di-dunia-positif-covid-19australia-nol-kasus-domistik-sejakjuni?utm_source=Mobile\&utm_mediu $\mathrm{m}=$ copylink\&utm_campaign=copylink .

WHO. 2020. "Novel Corona Virus." https://www.who.int/indonesia/news/no vel-coronavirus/qa-for-public. 